\title{
Molecular Detection of Alpha Thalassemia: A Review of Prevalent Techniques
}

\section{Alfa Talaseminin Moleküler Tespiti: Yaygın Tekniklerin Gözden Geçirilmesi}

\author{
Divashini VIJIAN $\odot$, Wan Suriana WAN AB RAHMAN $\odot$, Kannan Thirumulu PONNURAJ $\odot$, Zefarina ZULKAFLI $\odot$, \\ Noor Haslina MOHD NOOR ${ }^{\oplus}$
}

Ethics Committee Approval: Not Applicable.

Conflict of interest: The authors declare that they have no conflict of interest.

Funding: This study was funded by the Universiti Sains Malaysia Research University (individual) Grant (1001/PPSG/8012366).

Informed Consent: Not Applicable.
Cite as: Vijian D, Wan Ab Rahman WS, Ponnuraj KT, Zulkafli Z, Mohd Noor NH. Molecular Detection of alpha Thalassemia: A Review of Prevalent Techniques. Medeni Med J. 2021:36:257-69.

\begin{abstract}
Alpha thalassemia ( $\alpha$-thalassemia) is an autosomal recessive disorder due to the reduction or absence of $\alpha$ globin chain production. Laboratory diagnosis of $\alpha$-thalassemia requires molecular analysis for the confirmatory diagnosis. A screening test, comprising complete blood count, blood smear and hemoglobin quantification by high performance liquid chromatography and capillary electrophoresis, may not possibly detect all the thalassemia diseases. This review focused on the molecular techniques used to detect $\alpha$-thalassemia, and the advantages and disadvantages of each technique were highlighted. Multiplex gap-polymerase chain reaction, single-tube multiplex polymerase chain reaction, multiplex ligation-dependent probe amplification, and loop-mediated isothermal amplification were used to detect common deletion of $\alpha$-thalassemia. Furthermore, the reverse dot blot analysis and a single tube multiplex polymerase chain reaction could detect non-deletion mutation of the $\alpha$-globin gene. Sanger sequencing is widely used to detect non-deletion mutations of $\alpha$-thalassemia. Recently, next-generation sequencing was introduced in the diagnosis of both deletion and point mutations of $\alpha$-thalassemia. Despite the advantages and disadvantages of different techniques, the routine method employed in the laboratory should be based on the facility, expertise, available equipment, and economic conditions.
\end{abstract}

Keywords: Alpha chain, thalassemia, molecular techniques, deletion, non-deletion

Öz

Alfa talasemi ( $\alpha$-talasemi), $\alpha$ globin zincir üretiminin azalması ya da yokluğu nedeniyle otozomal resesif geçişli bir hastalıktır. $\alpha$-talaseminin laboratuvar tanısı, doğrulayıcı tanı için moleküler analiz gerektirmektedir. Yüksek performanslı sıvı kromatografisi ve kapiler elektroforez ile tam kan sayımı, kan yayması ve hemoglobin ölçümü içeren bir tarama testi, muhtemelen tüm talasemi hastalıklarını tespit edemeyebilir. Bu derleme, $\alpha$-talasemiyi saptamak için kullanılan moleküler tekniklere odaklanmıș ve her tekniğin avantaj ve dezavantajları vurgulanmıștır. Ortak $\alpha$-talasemi silinmesini saptamak için multipleks boşluk-polimeraz zincir reaksiyonu, tek tüplü multipleks polimeraz zincir reaksiyonu, multipleks ligasyona bağlı prob amplifikasyonu ve loop aracılı izotermal amplifikasyon kullanıldı. Ayrıca, ters nokta leke analizi ve tek tüplü multipleks polimeraz zincir reaksiyonu, $\alpha$-globin geninin delesyon olmayan mutasyonunu tespit edebilir. Sanger dizilimi, $\alpha$-talaseminin delesyon olmayan mutasyonlarını saptamak için yaygın olarak kullanılmaktadır. Son zamanlarda, $\alpha$-talaseminin hem delesyon hem de nokta mutasyonlarının tanısında yeni nesil dizileme tanıtılmıştır. Farklı tekniklerin avantaj ve dezavantajları olmasına rağmen, laboratuvarda uygulanan rutin yöntemler tesise, uzmanlığa, mevcut ekipmana ve ekonomik koşullara dayanmalıdır.

Anahtar kelimeler: Alfa zinciri, talasemi, moleküler teknikler, delesyon, silinmeme
Received: 06 May 2021

Accepted: 07 September 2021

Online First: 18 June 2020

Corresponding Author:

W.S. Wan Ab Rahman ORCID: 0000-0003-3878-208X

Universiti Sains Malaysia, Health campus, School of Dental Sciences, Kubang Kerian, Kelantan, Malaysia suriana@usm.my

D. Vijian ORCID: 0000-0002-2783-9178

K.T. Ponnuraj

ORCID: 0000-0001-5015-9771

Universiti Sains Malaysia,

School of Dental Sciences,

Kubang Kerian Kelantan, Malaysia

Z. Zulkafli

ORCID: 0000-0003-2029-2234 N.H. Mohd Noor

ORCID: 0000-0001-8357-1850 Universiti Sains Malaysia, School of Medical Sciences, Department of Hematology, Kubang Kerian Kelantan, Malaysia 


\section{INTRODUCTION}

Red blood cells (RBCs) primarily function to transport oxygen to all parts of the body tissue, with hemoglobin $(\mathrm{Hb})$ being its main component. Adult hemoglobin ( $\mathrm{Hb} \mathrm{A}$ ) is a tetrameric protein that consists of two alpha $(\alpha)$ and two beta $(\beta)$ globin chains, each comprising a pocket containing the haem group for oxygen binding ${ }^{1}$. Haem is a ring-like organic compound known as porphyrin, to which an iron atom is attached. Oxygen molecules will bind to the iron atom. Therefore, each $\mathrm{Hb}$ will carry four oxygen molecules ${ }^{2}$. The globin genes are located in two separate gene clusters on different chromosomal loci ${ }^{1}$. The $\alpha$-like and $\beta$-like genes are located on chromosomes 16 and 11 respectively ${ }^{3}$, as shown in Figure 1. The genetic defect in these globin genes will lead to either the reduction or absence of $\alpha$-chain or $\beta$-chain production. The $\alpha$-like gene cluster is close to the telomere of chromosome 16 (16p13.3), which includes an embryonic gene (६) and two foetal/adult genes arranged along the chromosome surrounded by widely expressed genes ${ }^{4}$. These globin gene disorders (hemoglobinopathies) are characterized either by the production of abnormal globin chain variants (like sickle cell anaemia), or reduced globin chain synthesis (thalassemia) during hematopoiesis ${ }^{5}$.

Alpha-thalassemia ( $\alpha$-thalassemia) has a complex genetic inheritance because the disorder involves HBA1 and HBA2 genes ${ }^{6}$. There are four functional $\alpha$-globin genes in a normal individual ${ }^{7}$ and each individual inherits two $\alpha$-globin alleles from each parent ${ }^{8}$. Deletion of one or both $\alpha$-gene from chromosome 16 occurs in $95 \%$ of cases, which results in the reduction of $\alpha$-globin chain expression? ${ }^{9}$. Besides, this mutation will decrease the RNA synthesis, processing, or stability, leading to protein synthesis reduction ${ }^{10}$. The minority cases occur due to point mutations, resulting in severe clinical presentation ${ }^{10}$. In fetus, the defective production of $\alpha$-chains is reflected by the presence of excess $\gamma$-chains, which form $\gamma 4$ tetramers, which is called $\mathrm{Hb}$ Bart's. In adults, excess $\beta$-chains form $\beta 4$ tetramers, which is known as $\mathrm{Hb} \mathrm{H}^{11}$. Figure 2 shows the phenotypic expression and types of $\alpha$-thalassemia. The severity of $\alpha$-thalassemia depends on the number of missing alleles that are inherited from the parents. In some rare conditions, large deletions

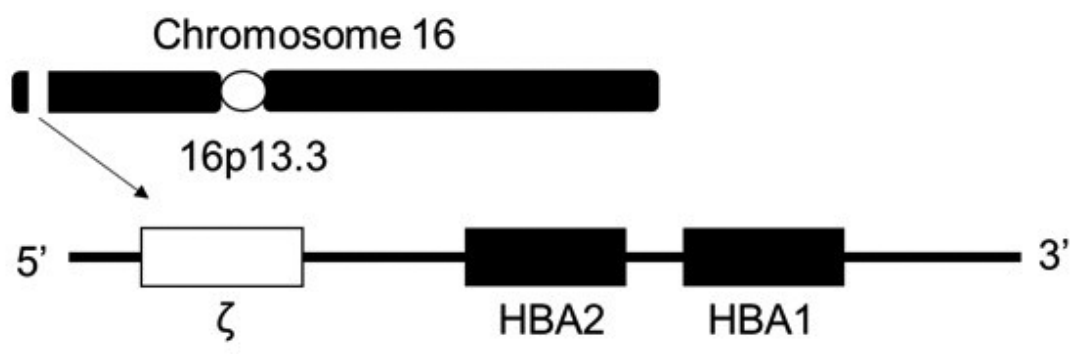

Chromosome 11

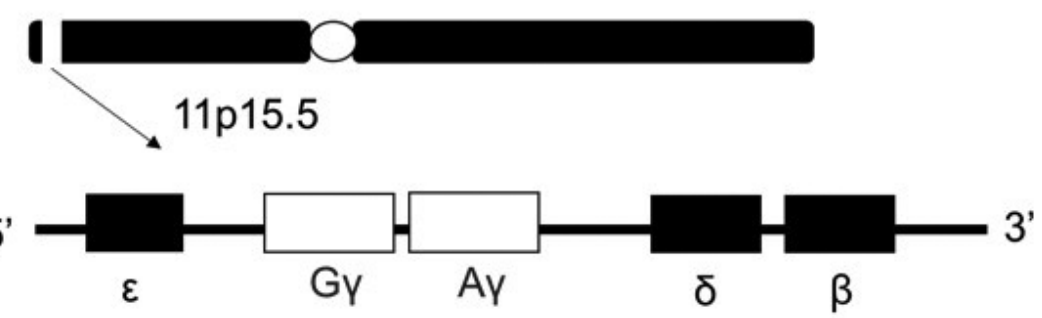

Figure 1. Schematic diagram of the chromosomal location of $\alpha$ and $\beta$ gene. 
in $16 p 13.3$ will cause the removal of $\alpha$ globin genes, and many other genes located around the related gene cluster will result in ATR16 syndrome, OMIM:141750. The individual with this syndrome will have $\alpha$-thalassemia because the $\alpha$ genes are deleted. Therefore, a similar clinical phenotype to $\alpha$-thalassemia is presented. Besides abnormal development, intellectual disabilities and dysmorphic features are common symptoms of this syndrome ${ }^{1,12}$. ATR-X syndrome, OMIM:301040, is another rare syndrome associated with $\alpha$-thalassemia. This is $X$ linked with a mutated gene of ATRX located on Xq13.3. In normal circumstances, the ATRX protein acts as a transcriptional regulator, influencing the expression of $\alpha$-globin gene. Therefore, a decrease in the expression of $\alpha$ globin chains causes $\alpha$-thalassemia. Patients may have presented with severe mental disability, developmental delay, and craniofacial anomalies ${ }^{1}$.

More than 300,000 individuals are severely affected by thalassemia throughout the world each year ${ }^{4}$, and specifically, 5\% of the world's population are affected with $\alpha$-thalassemia ${ }^{13}$. $\alpha$-thalassemia was reported to be high in the Southeast Asia, the Mediterranean, sub-Saharan Africa, the Middle East, and India. The disease is also widely distributed in the northern European countries and North America due to massive migration of these populations ${ }^{14}$. Up to $40 \%$ of individuals are carriers of $\alpha$-thalassemia in the regions of the Mediterranean and the Middle East. Furthermore, Turkey reported a high distribution of this disease with an incidence rate of $0.25 \%-4.1 \%{ }^{15}$.

\section{Diagnosis of $\alpha$-thalassemia}

Pathologic defects on the globin chain are characterized by quantitative or qualitative abnormality. The quantitative defects include $\alpha$-thalassemia and $\beta$-thalassemia, which are due to reduced $\alpha$-globin production and $\beta$-globin production. These types of globin defects' interaction results in a wide variety of clinical presentation and diseases ${ }^{5}$. Clinically, $\alpha$-thalassemia is classified into thalassemia minor, intermedia, and major. Patients with thalassemia minor (or thalassemia trait) are usually asymptomatic or present with mild anemia. The individual with thalassemia intermedia represents a highly diverse group of patients with various clinical severities, ranging from mild to severe anemia. Some patients may not require blood transfusion, while others may need blood transfusion frequently. Patients with thalassemia major present with severe anemia in early life require regular blood transfusion and iron chelation ${ }^{16}$. In $\alpha$-thalassemia, the reduced $\alpha$-globin synthesis causes the accumulation of excess polypeptide ( $\beta$ globin chain) encoded by the unaffected gene. Therefore, imbalance in $\alpha$-globin chains and $\beta$-globin chains cause abnormal maturation of RBCs, resulting in microcytosis ${ }^{10}$. The clinical phenotype of $\alpha$-thalassemia depends on the number of genes affected because a normal individual carries four functional $\alpha$-genes. Inactivation or deletion of one $\alpha$-gene results in a silent carrier of $\alpha$-thalassemia, with insignificant hematological findings. Two affected $\alpha$-globin genes result in microcytic hypochromic anemia. In diagnostic practice, the annotation $\alpha^{+}$or $\alpha^{0}$ is used to describe a patient's genetic defect. In $\alpha^{+}$-thalassemia, there is a deletion or inactivation in one of the $\alpha$-globin genes $(-\alpha / \alpha \alpha$ or $\alpha \alpha \mathrm{ND} /$ $\alpha \alpha$, with ND denoting non-deletion), while $\alpha^{0}$-thalassemia indicates deletion of both $\alpha$-globin genes in cis $(--/ \alpha \alpha) .^{5}$. Three $\alpha$-globin genes deletion or mutation leads to $\mathrm{Hb} \mathrm{H}$ disease, resulting in moderate anemia and marked microcytosis. Hb Bart's hydrops fetalis is the most severe form of $\alpha$-thalassemia, in which all four $\alpha$-globin genes are affected and often cause intrauterine death ${ }^{17}$. Infants with $\mathrm{Hb}$ Bart's hydrops fetalis have variable amounts of non-functional $\mathrm{Hb} \mathrm{H}\left(\beta_{4}\right)$ and $\mathrm{Hb}$ Bart's $\left(\gamma_{4}\right)$, and functional $\mathrm{Hb}$ Portland $\left(\zeta_{2} \gamma_{2}\right){ }^{1}$. There will be excess in Hb Bart's, which results in severe anemia (Hb level 3-8 g/ 


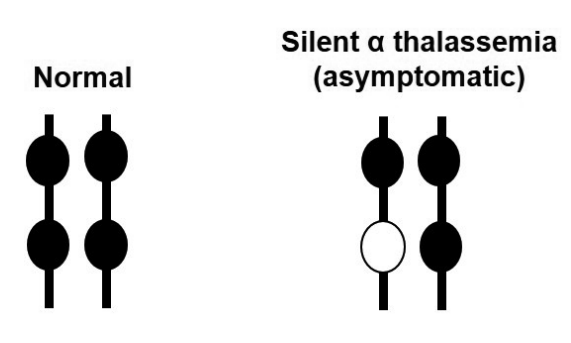

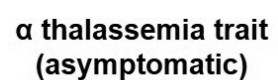

(asymptomatic)

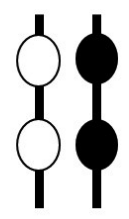

OR

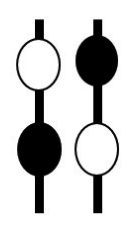

: Functional $\alpha$ gene

: Non-functional $\alpha$ gene

Figure 2. Phenotypic expression and types of $\alpha$-thalassemia.

$\mathrm{dL}$ ), marked hepatosplenomegaly, and cardiac failure. Maternal complications during pregnancy, such as preeclampsia (hypertension and fluid retention, with or without proteinuria), polyoligohydramnios (increased or reduced accumulation of amniotic fluid, respectively) hemorrhage, anemia, and sepsis may occur ${ }^{18}$.

Clinical presentation of $\alpha$-thalassemia may vary as it has high variability in the genetic defect. Generally, the $\mathrm{Hb}$ level in $\alpha$-thalassemia varies from normal to severe anemia (Hb 7.5-15.5 g/ dl). Meanwhile, there is a reduction of mean corpuscular volume (MCV $<79 \mathrm{fl})$, mean corpuscular hemoglobin $(\mathrm{MCH}<27 \mathrm{pg}$ ), and normal to slight decrease in $\mathrm{HbA2}$ level, depending on the number of functional $\alpha$-globin genes ${ }^{1}$.

\section{Routine Screening of Thalassemia}

Screening of $\alpha$-thalassemia is essential to identify those couples with high risk, especially severe forms of the disease that occur in high-frequency areas. It also helps to prevent severe maternal complications in the case of $\mathrm{Hb}$ Bart's and provides accurate diagnosis in patients with concomitant iron deficiency, or coinherited with
Hb H Disease (symptomatic)
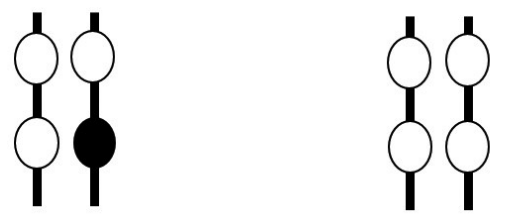

Hb Bart's Hydrops Fetalis

OR

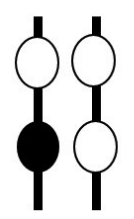

HbS or $\beta$-thalassemia ${ }^{11}$. Diagnosis of $\alpha$-thalassemia requires a combination of several laboratory tests; complete blood count (CBC), blood smear and $\mathrm{Hb}$ quantification by high-performance liquid chromatography (HPLC) and capillary/gel electrophoresis ${ }^{19}$. Most $\alpha$-thalassemia traits are asymptomatic and identified only by chance after routine hematological analyses. However, reduction in $\mathrm{Hb}$ level may occur when there is concomitant blood loss, infection, poor nutrition, or other disease that may lead to symptomatic anemia ${ }^{1}$.

\section{Complete Blood Count and Blood Smear}

In an automated blood cell analyzer for $\mathrm{CBC}$, the sample is aspirated and separated into different fluidic streams, containing different buffer solutions to obtain the specific purpose of analysis. Each parameter is measured under flow cytometry, as a single cell in a fluidic stream passing through a laser beam, and signals are collected from a series of detectors ${ }^{16}$. RBC indices, such as $\mathrm{MCV}$, $\mathrm{MCH}$, and mean corpuscular hemoglobin concentration $(\mathrm{MCHC})$ levels are calculated from $\mathrm{Hb}$, hematocrit, and $\mathrm{RBC}$ count. In thalassemia screening, MCV levels of less than $80 \mathrm{fL}$ and $\mathrm{MCH}$ of less than 27 pg are used as cut-off levels for a 
positive screening result ${ }^{20}$. Therefore, $\mathrm{MCV}$ and $\mathrm{MCH}$ values might also be low due to iron deficiency anemia (IDA) and anemia of chronic disease, as found in the thalassemia trait ${ }^{16}$. Therefore, another laboratory method is required to confirm the thalassemia disease.

In thalassemia, RBC morphology showed microcytic, hypochromic, apparent anisocytosis, and poikilocytosis. Microcytic anemia among thalassemia patients is due to impaired globin chain synthesis, which lead to a decrease in $\mathrm{Hb}$ synthesis ${ }^{21}$. Interpretation of blood smear based on RBCs morphology solely is not possible to define thalassemia disease as those interpretations can also be detected in IDA $^{16}$. A blood smear stained with brilliant cresyl blue shows inclusion bodies in the RBCs, indicating the presence of $\mathrm{Hb}$ $\mathrm{H}^{22}$. These red cells are unstable, destroyed prematurely in the spleen and result in moderate to severe hemolysis ${ }^{23}$. Hence, HPLC and capillary/ gel electrophoresis (CE) is used to distinguish between thalassemia disease and thalassemia trait by quantifying each $\mathrm{Hb}$ level ${ }^{19}$.

\section{High-performance Liquid Chromatography (HPLC)}

HPLC separates molecules (normal and variant $\mathrm{Hbs}$ ) with a net positive charge into its component by adsorption onto a negatively charged stationary phase in a column, followed by elution. Retention times (time of solute spends in a column), shape of the curve or peak, and percentage produced vary among different Hbs. The area under each peak is integrated to provide the percentage and retention time ${ }^{24}$. The main advantages of this technique are its sensitivity, precise method for quantitative analyzes of $\mathrm{Hb}$ components, excellent resolution, and reproducibility ${ }^{22}$. HPLC measures $\mathrm{HbA2}, \mathrm{Hb} F$, and $\mathrm{Hb}$ variants, which helps to identify normal and abnormal levels of $\mathrm{Hb}$ in a blood sample ${ }^{25}$. HbA2 level plays an important role in $\beta$-thalassemia screening program, wherein if the value is more than $4 \%$, the individual is presumed as $\beta$-thalassemia carrier ${ }^{26}$. However, borderline HbA2 level needs further evaluation for silent mutations, $\alpha$-thalassemia, and the co-existing nutritional deficiency ${ }^{22}$. Excess $\beta$-chains in $\mathrm{Hb} \mathrm{H}$ disease result in the production of $\mathrm{Hb} \mathrm{H}$ and reduction in $\mathrm{HbA} 2$ level. Therefore, detection of $\mathrm{Hb} \mathrm{H}$ and $\mathrm{Hb}$ Bart's are important for diagnosis ${ }^{16}$. However, even though HPLC is automated and able to distinguish different $\mathrm{Hb}$, it has limitation in detecting and quantifying $\mathrm{Hb} \mathrm{H}$ and $\mathrm{Hb}$ Bart's percentage ${ }^{19}$. It has low sensitivity in detecting $\mathrm{Hb}$ constant spring (CS), an $\alpha$-globin variant ${ }^{16}$.

\section{Capillary Electrophoresis (CE)}

$\mathrm{CE}$ is used to separate $\mathrm{Hb}$ fractions and quantify each fraction level ${ }^{27}$. CE separates and quantifies $\mathrm{Hb} \mathrm{A}_{2}, \mathrm{Hb} \mathrm{E}, \mathrm{Hb} \mathrm{F}, \mathrm{Hb} \mathrm{H}, \mathrm{Hb}$ Bart's and some $\mathrm{Hb}$ variants. These parameters are required to diagnose $\alpha$ and $\beta$-thalassemia, and hemoglobinopathies ${ }^{28}$. The charged molecules are separated by their electrophoretic mobility in an alkaline buffer and packed cells are hemolyzed with hemolyzing solution after plasma is discarded ${ }^{29}$. The $\mathrm{Hb}$ fractions are detected directly at a wavelength of $415 \mathrm{~nm}$, which is optimal to $\mathrm{Hb}$, in the following order from cathode to anode: $\mathrm{Hb}$ C, A2, E, S, D, F, A, Bart's, J and $\mathrm{H}^{27}$. Advantages of $\mathrm{CE}$ include the turn-around time, high throughput, small sample volume requirement, and reasonable cost. The CE system can also quantify $\mathrm{Hb} \mathrm{H}$ and $\mathrm{Hb}$ Bart's levels, which is a limitation in the HPLC system ${ }^{28}$. Otherwise, the levels of $\mathrm{Hb} \mathrm{H}, \mathrm{Hb}$ Bart's, and $\mathrm{Hb}$ CS are decreased in stored blood samples, especially at high temperatures as these $\mathrm{HbS}$ are unstable $^{19}$. The $\mathrm{Hb} \mathrm{H}$ has a short life span of 12 to 19 days as compared to normal 28 to 37 days. Factors that lead to unstable $\mathrm{Hb} \mathrm{H}$ are abnormal RBC membrane with increased rigidity and increased inclusion bodies ${ }^{30}$. This limitation can be overcome by using fresh blood sample. However, molecular analysis is still required to fully understand the clinical phenotype and the 
definitive diagnosis ${ }^{31}$. Therefore, molecular diagnosis of DNA sequence is the most decisive diagnosis. Currently, there are several molecular techniques to study the molecular basis of the globin gene defects, as detailed below ${ }^{16}$.

\section{Molecular Diagnostic Techniques}

Molecular genetic testing plays an essential role in the diagnosis of $\alpha$-thalassemia. Genetic testing conducted during the antenatal period will identify fetuses with severe globin phenotypes ${ }^{10}$. DNA analysis has tremendously evolved as compared to that in the past 40 years ${ }^{1}$. Recently, known and unknown mutations can be diagnosed by using many different polymerase chain reaction (PCR) based techniques and DNA sequencing ${ }^{27}$.

\section{Dot Blot Analysis}

In dot blot (DB) analysis, amplified DNA is immobilized on a nitrocellulose or nylon membrane. The principle of the dot blot (DB) and reverse dot blot $(\mathrm{RDB})$ techniques is that the allele specific oligonucleotide probes (ASO) as hybridization targets for the amplified DNA molecule that complements the oligoprobe ${ }^{32}$. This allows direct detection of point mutations or minor deletions that occur in the gene of interest ${ }^{33}$. In both blot techniques, the amplified DNA labelled with biotin for colorimetric detection will be hybridized to the probes which are bound to the membrane, $\mathrm{RDB}^{19}$ or in $\mathrm{DB}$, applied a radioactively labelled probe to DNA samples attached to a membrane in the form of a dot. It uses a non-radioactive material in RDB and washes and hybridizes at the same temperature, whereas DB requires radioactive substances with a different temperature for washing and hybridization. Therefore, the DB analysis can detect one mutation in many samples on a membrane, while in the case of $\mathrm{RDB}$, many mutations can be detected in a sample per membrane $^{32}$. Furthermore, in both techniques probes of normal sequence and mutant sequences are included to detect the homozygosity or heterozygosity in individuals ${ }^{19}$. RDB analysis is widely used to detect the non-deletional mutation, resulting in $\alpha$-thalassemia, as in a single test different mutations of a sample are identified. The advantages of this technique are that it can distinguish the homozygous and heterozygous states of an individual ${ }^{34}$, simple, rapid, and reliable. However, its limitations are that it requires a trained and expert personnel to set up the test and sample controls are needed for the identification of new mutations ${ }^{32}$.

\section{Gap-polymerase Chain Reaction (Gap-PCR)}

The Gap-polymerase chain reaction (Gap-PCR) technique is currently used to detect common deletion types of $\alpha$-thalassemia. The amplification of the $\alpha$-globin gene cluster for DNA diagnosis is more challenging due to considerable sequence homology within the $\alpha$-globin gene cluster ${ }^{35}$. This technique amplifies the DNA sequence by using the primers flanking the deleted region ${ }^{36}$. Three primers are designed for each deletion to amplify the normal gene and deleted gene sequences ${ }^{37}$. Gap-PCR is a rapid screening method for the most common seven types of deletion in $\alpha$-thalassemia ${ }^{1}$, which are - ${ }^{\mathrm{THAI}}$, — ${ }^{\mathrm{SEA}},-^{\mathrm{FIL}},-^{\mathrm{MED}},-\alpha .^{20.5},-\alpha .^{3.7}$ and $-\alpha .227$. The main advantage of using Gap-PCR is a quick diagnostic test for $\alpha^{0}$ and $\alpha^{+}$thalassemia. However, this is time-consuming because its conventional method requires post-PCR work, and thus not suitable for large-scale screening. Therefore, a study was conducted, whereby GapPCR was combined with high resolution melting (HRM) to detect $\alpha^{\text {SEA }}$ type deletion. The HRM analysis is a method which use melting temperature $(\mathrm{Tm})$ profiles in the post-PCR to identify the genotypes ${ }^{36}$. The $\mathrm{Tm}$ is temperature when half of the double-stranded DNA has broken down to become a single-stranded DNA. The Tm of the DNA duplex changes is detected during the break down of a double-stranded DNA to single-stranded DNA. Therefore, the differences in the Tm profile enable the identification of 
different genotypes. The DNA templates are amplified with forward and reverse primers, dNTP mixture, $\mathrm{MgCl} 2$, and Taq polymerase. Next, HRM analysis requires a double-stranded DNA-binding fluorescent dyes and additional DNA melting steps. When Tm is attained, the fluorescent dye is released, and there is a decrease in fluorescence signal. Finally, based on the mean and standard deviation of Tm, DNA samples are accurately genotyped in HRM analysis ${ }^{36}$. Gap-PCR with HRM analysis is suitable for large-scale and prenatal screening as it is cost-effective, sensitive, and a straightforward technique ${ }^{38}$. The Gap-PCR with HRM analysis is preferred as an alternative technique because it has a simpler work flow without the need to process the PCR product in polyacrylamide gel electrophoresis, and it is suitable for clinical applications ${ }^{39}$. Prenatal screening with Gap-PCR is achievable by using cell-free fetal DNA (cffDNA) in the maternal plasma. Maternal plasma DNA consists of approximately 3-20\% of trophoblastic cell-derived cffDNA. The cffDNA consists of a shorter sequence than maternal DNA. Therefore, an amplification and few steps are required for the identification and is proceeded with PCR and HRM analysis to detect mutation in the fetal $\mathrm{DNA}^{40}$.

\section{Single-tube Multiplex Amplification Refractory Mutation System Polymerase Chain Reaction}

Single-tube multiplex amplification refractory mutation system (ARMS) PCR can be used for rapid detection of deletion ${ }^{41}$ or non-deletion mutations of $\alpha$-thalassemia ${ }^{42}$. ARMS technique is also known as allele-specific PCR. ARMS is a PCRbased system that differentiates between normal and mutant alleles by selecting primers with a nucleotide at their 3' end corresponding to either normal or mutant sequence. Amplification of DNA fragments only happens if there is a perfect match with the genomic sequence to which the primer is annealing. In a single tube multiplex PCR, all targeted mutations will be carried out in a tube. Therefore, a unique fragment length is generated for each mutation by using two primers, including forward and reverse primer. The primers will be complementary and specific for the mutant allele. After the amplification of targeted DNA, the product will be analyzed by gel electrophoresis $^{42}$. Single-tube multiplex PCR is used to detect six common and severe nondeletional $\alpha$-globin gene found among the Southeast Asian populations, including initiation codon (ATG>A-G; HBA2:c.2delT), codon 30 (HBA2:c.91_93delGAG), codon 35 ( $\alpha 2-35$, Ser $\rightarrow$ Pro), codon 59 (HBA2(or HBA1):c.179G>A) (Hb Adana), codon 125 (HBA2:c.377T>C) (Hb Quang Sze) and termination codon (HBA2: c.427T $>$ C) (Hb Constant Spring $)^{42}$. This is a rapid and reliable way to identify common non-deletion mutations among those carrying $i^{42}$. Apart from that, single-tube multiplex PCR was established to detect $\alpha^{3.7}$ and $\alpha^{4.2}$ in a study ${ }^{42}$. Another study conducted with a similar technique could identify six common single and double gene deletions ${ }^{43}$. The single gene deletion detected in the study was $-\alpha . .^{3.7}$ and $-\alpha .{ }^{4.2}$, while the double gene deletion identified were - ${ }^{\mathrm{SEA}}$, - - ${ }^{\mathrm{FL}}$, - ${ }^{\mathrm{MED}}$, and $-\alpha .^{20.543}$. This technique is simple, rapid, and reliable for a larger population for epidemiological screening in common deletion ${ }^{41}$ and nondeletional $\alpha$-thalassemia ${ }^{42}$. Previously, the Southern blot technique was used, which was time-consuming, expensive, and labor intensive. Despite being effective for individual screening, the use of Southern blot in large-scale population screening was challenging. PCR method is relatively simple and cost-effective for the detection of $\alpha$-thalassemia mutations. However, the PCR technique solely requires multi-tube, making it difficult for large epidemiological screening. Therefore, multiplex PCR carried out in a single tube for detecting the mutations was established. This technique is more suitable for large population screening ${ }^{41}$. In a recent study, single-tube multiplex PCR was able to detect $\alpha \alpha \alpha^{\text {anti } 3.7}$ triplications of $\alpha$-gene deletion together with other common deletion, making this technique less laborious and less expensive than 
other methods ${ }^{44}$. However, multiplex ARMS-PCR is less valuable in ethnically diverse populations ${ }^{10}$.

\section{Multiplex Ligation-dependent Probe Amplification}

The multiplex ligation-dependent probe amplification (MLPA) technique is suitable for rapid and quantitative analysis ${ }^{45}$. MLPA involves annealing of two adjacent oligonucleotides to a segment of genomic DNA followed by quantitative PCR amplification to characterize copy number or other changes in the DNA ${ }^{46}$. MLPA technique requires only thermocycler and $\mathrm{CE}$ equipment. This technique starts with the DNA denaturation or hybridization step. After DNA denaturation, the sample is incubated with a mixture of MLPA probes, which consists of two separate oligonucleotides, including right probe oligonucleotides (RPO) and left probe oligonucleotides (LPO). The two probes will be hybridized to the adjacent target sequence. The probes will be ligated during ligation reaction, and only ligated probes will be amplified during the PCR reaction. The number of target sequences in a sample is measured by the probe ligation products. Finally, amplification products are separated by using CE, and the data are analyzed by using a specific software ${ }^{19}$. The MLPA is able to detect large common and uncommon deletion, and $\mathrm{Hb}$ CS (non-deletional) mutation ${ }^{47}$. This technique can also determine the actual extension of the rearrangements by analyzing with $\alpha$-globin gene cluster in one experiment ${ }^{48}$. The southern blotting technique was used previously and still used in some laboratories to detect unknown deletions of $\alpha$-thalassemia. However, this technique is currently replaced with MLPA as MLPA is more sensitive and reliable, and does not require the use of radioactive detection as in the southern blotting method ${ }^{49}$. MLPA produces reliable results even with partially degraded DNA samples, while Gap-PCR cannot amplify old or semi-degraded DNA samples and requires a novel genomic DNA extraction ${ }^{48}$.

\section{Loop-mediated Isothermal Amplification}

Loop-mediated isothermal amplification (LAMP) is a novel method for nucleic acid amplification in molecular diagnostics as it is highly sensitive, specific, rapid, accurate, and cost-effective ${ }^{50}$. This technique requires four to six primers for six regions on the targeted gene, and the primer sets are specific to the target areas ${ }^{51}$. Therefore, it has a higher amplification product and rapid amplification than the PCR-based method ${ }^{52}$. Target DNA is obtained through genomic DNA extraction, and primers are specifically designed based on the type of mutation sequences to be detected. This technique requires forward inner primer (Forward 1 complementary, F1c and F2), backward inner primer (Back 1 complementary, B1c and B2), two outer primers which are described as a forward outer primer (F3), and backward outer primer (B3), corresponding to the target gene sequence of six different regions. The forward loop primer and backward loop primer are designed to accelerate the amplification reaction. All primers, including two inner primers, and two outers primers $\mathrm{F} 3$ and $\mathrm{B} 3$, play important roles in the LAMP reaction ${ }^{53}$. Figure 3 shows the schematic diagram of LAMP reaction at different stages in the process. Based on Figure 3, elongation of the strands by $\mathrm{F} 3$ and B3 external primers occurs with the help of DNA polymerase, which leads to the formation of a dumbbell-shaped DNA structure. Then, the structure formed will act as the LAMP initiator, whereby forward inner primer will attach to the DNA structure and initiate the synthesis of the strand as in Figure 3. Next, the releasing strand generates a structure with an external loop, which is the pattern for the backward inner primer polymer. The amplification produces stemloop DNA structures with numerous repeats of the target and cauliflower-like structures with multiple loops as end products. Furthermore, loop primers also reduce the amplification time, and specific designed oligonucleotides probe to 


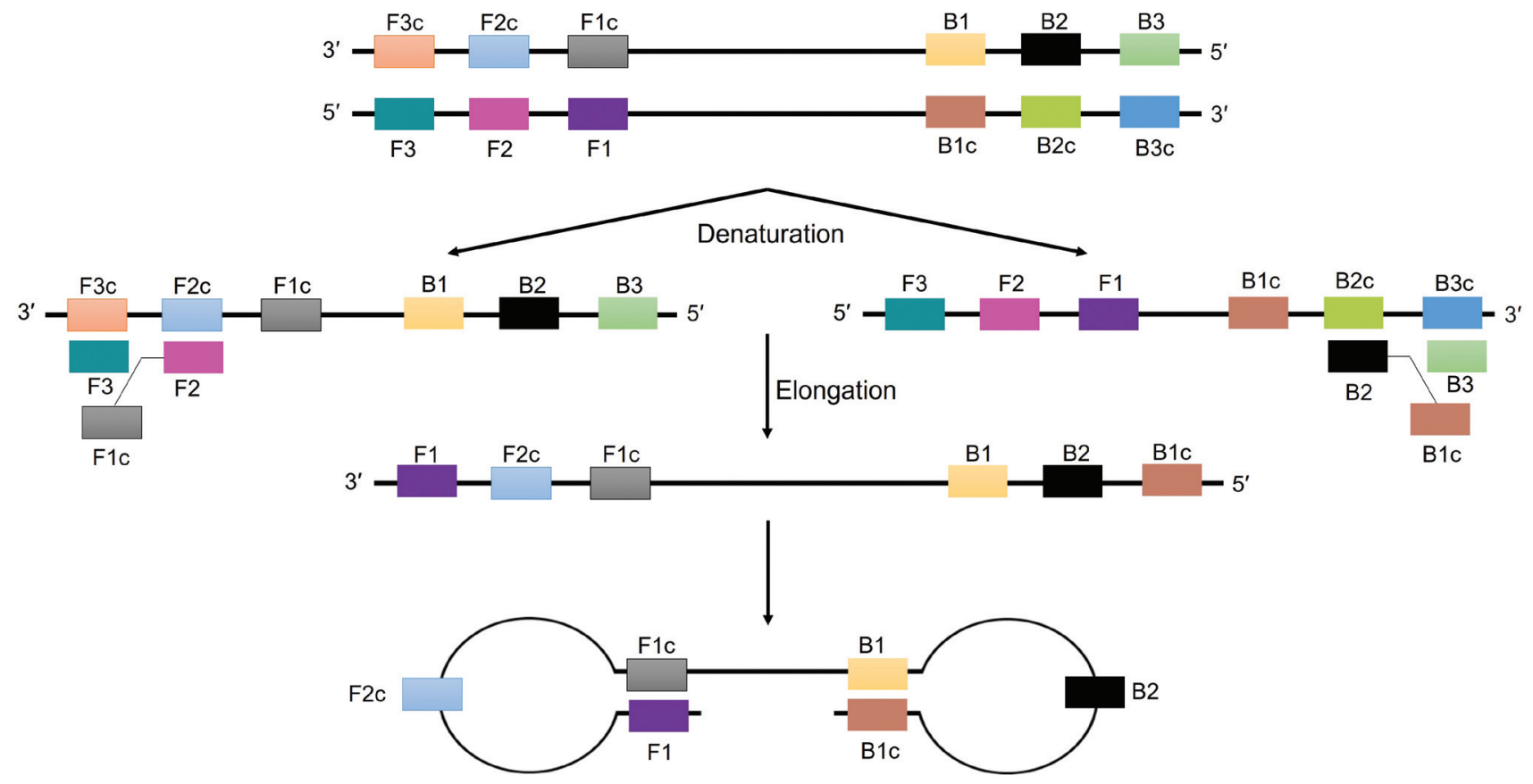

Figure 3. Schematic diagram of LAMP reaction.

the DNA structure can be applied in hybridization. Therefore, there is no need for heat denaturation after the multiplication. The steps from multiplication to detection can be conducted at the same temperature ${ }^{54}$. The reaction is observed with naked eyes based on turbidity due to the production of magnesium pyrophosphate ${ }^{54}$, as this demonstrates the absence of the target gene, making it ideal for easy monitoring. In recent years, the use of SYBR Green dye has made this step convenient ${ }^{53}$. In addition, this technique does not require detection by electrophoresis. Instead, it needs a constant temperature water bath or metal bath. The results can be directly observed under an ultraviolet (UV) lamp with the naked eye as compared to traditional PCR, which requires a special PCR instrument ${ }^{51}$. Studies found that the LAMP method could detect deletional type of $\alpha$-thalassemia, including $\alpha^{\text {SEA }}, \alpha^{\text {THAI }}, \alpha^{3.7}$, $\alpha^{4.2}$, and $\beta$-thalassemia mutations ${ }^{51}$. PCR technique is a standard method for laboratory-based DNA detection. However, this method requires high set-up, operating expenses, and high precision equipment. Therefore, the LAMP technique was introduced as a potential gene amplification assay with high sensitivity, specificity, simplicity, and it is cost-effective, eliminating the need for highly sophisticated thermocycling equipment ${ }^{55}$. However, the LAMP method is commonly used to detect the deletional type of $\alpha$-thalassemia, and it is rarely used for genotyping and identifying point mutation ${ }^{52}$. Furthermore, $\alpha^{4.2}$ and $\alpha^{3.7}$ deletion showed a false-positive result in the LAMP technique in a study. Deletion genes were closely related to wild-type gene sequence before mutation, which was more likely to have false amplification $^{51}$. However, this condition was overcome in the $\mathrm{pH}$-sensitive LAMP technique. The LAMP method is coupled with phenol red. This association showed high specificity in detecting abnormal $\alpha$-globin genes. Moreover, there is no cross-reactivity with $\alpha^{4.2}$ and $\alpha^{3.7}$ deletion $^{50}$.

\section{DNA Sequencing}

DNA sequencing analysis is a gold standard method for the screening of unknown nondeletion mutations ${ }^{56}$. Specifically, Sanger DNA sequencing is the most inclusive method to 
detect all mutations of non-deletional type of $\alpha$-thalassemia as this avoids having the necessity to design mutation-specific assays ${ }^{10}$. However, HBA gene sequencing by the Sanger method is methodologically complex as the position of HBA1, and HBA2 genes on chromosome 16 are nearly identical for a stretch of over one-kilo bp that includes the 5' and 3' flanking regions, coding sequences, and introns. For a selective amplification of both $\alpha$-globin genes, one needs to use sequences of at least 1000 base pairs 5' to the structural genes to design specific PCR primers for each of the $\alpha$-genes. However, this 5' primer can be combined with a common 3' primer. Other than that, the sequence of HBA is relatively guanine and cytosine rich ${ }^{10}$. Therefore, optimizing standard PCR conditions can efficiently amplify this sequence ${ }^{57}$. Successfully amplified PCR products can be sequenced directly by using the Sanger method ${ }^{10}$. In this method, four ddNTPs, dideoxynucleotide phosphates such as ddATP, ddTTP, ddCTP, and ddGTP are labeled with different fluorochrome dyes so that the laser beam can detect them. Each fluorescent-labeled terminated fragment of DNA is recorded, and by using software, the DNA sequence is generated. However, in the Sanger sequencing method, the PCR cycle is repeated several times to have all the positions of the DNA template; hence, unique fluorescence-labeled A, T, C, and G of DNA chains are produced ${ }^{58}$. The obtained sequence can be compared with those in the Database of Human Hemoglobin Variants Thalassemia to determine clinical significance ${ }^{10}$.

Advancement in genetic sequencing technology has introduced a new sequencing technique known as next-generation sequencing (NGS). This technology has gained capacity to sequence the entire human genome as the sequencing capacity increases from several hundred to several thousand base pairs in analysis ${ }^{35}$. Generally, NGS comprises three steps; the first is the library preparation by using random fragmentation of DNA, followed by ligation with custom linkers.
Second, by using clonal amplification and PCR, the library is amplified. Third, sequencing is generated by incorporating fluorescent-labeled nucleotides by DNA polymerase or ligation processes ${ }^{19}$. Sanger and NGS have similar principles, whereby dye-labeled nucleotides are added to the DNA strand, and the DNA is sequenced based on fluorescence emitted by each base pair. NGS is widely used to diagnose and understand complex diseases through wholegenome sequencing, targeted gene panels, and exome sequencing. Recently, NGS was established for thalassemia screening, whereby target NGS approach was designed to cover the entire globin gene coding regions, key regulatory regions, and modifier genes ${ }^{19}$. Therefore, NGS is most probably more accurate than the conventional method. To strengthen this point, a study conducted in China reported that PCR-NGS revealed rare and common mutations that were missed by the conventional method ${ }^{19}$. Furthermore, the NGS approach used to screen for thalassemia minimizes the risk of false-negative results and misdiagnoses, as well as the necessity for additional blood sampling and referral testing. As a result, this technique is a generally performed screening procedure in areas with high frequency of thalassemia ${ }^{59}$. The NGS technique is demonstrated as a screening and confirmation method in the high prevalence of $\alpha$-thalassemia populations ${ }^{60}$. NGS thalassemia kits are commercially available to detect the sequence variants of $\alpha$ and $\beta$ genes. However, thalassemia screening with NGS is difficult, timeconsuming, and expensive due to high homology between the genes in $\alpha$ - and $\beta$-clusters. Therefore, the Sanger sequencing method is the best method for detecting point mutation and variants in thalassemia, but it is unable to identify deletion mutations in thalassemia. Simultaneously, NGS can characterize both deletion and non-deletion throughout all globin genes in parallel ${ }^{10}$. NGS is more costly as sequencing involves only two genes for thalassemia, which does not justify the cost of the entire procedure for a single patient ${ }^{35}$. Therefore, the Sanger method is more cost- 


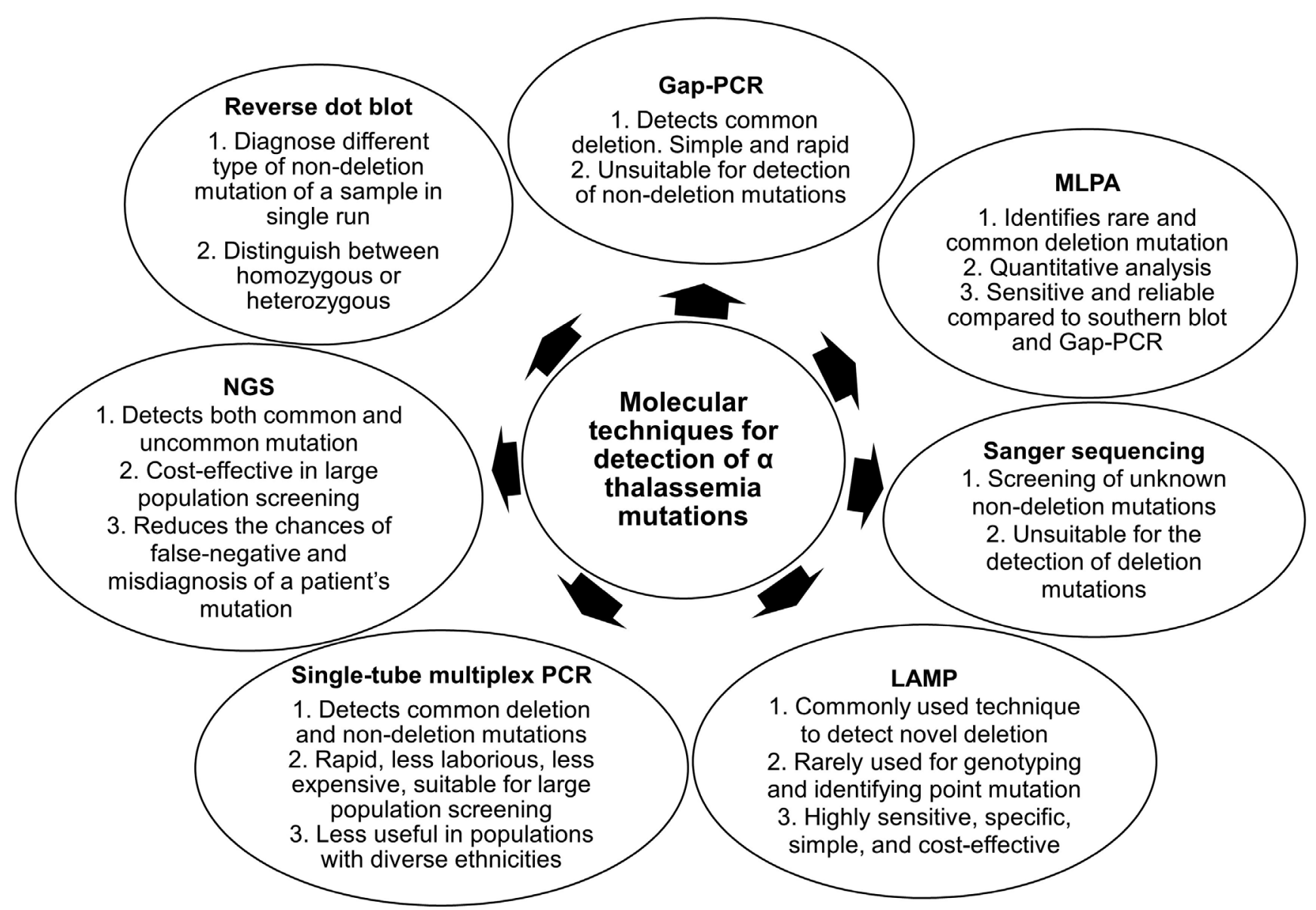

Figure 4. Different molecular techniques used in the diagnosis of $\alpha$-thalassemia.

effective than NGS for thalassemia diagnosis in a single patient.

Briefly, long-read sequencing can detect thalassemia screening after generating long fragments that consist of HBA and HBB genes and further with long molecule sequencing. In this technique, the entire sequence of both alleles will be analysed with bioinformatics tools to identify the changes in sequence. This test is known as accurate and cost-effective for thalassemia carrier screening. Furthermore, this test provides information on either the compound heterozygous is in cis or trans. This technique analyzed the entire gene region; hence, variants including silent $\alpha$-thalassemia trait, $\mathrm{Hb}$ CS trait, and other rare deletion and non-deletional mutations are detectable. Besides, the sequence analyzes the HBA and HBB genes simultaneously.
Therefore, it is capable of confirming other minor thalassemia traits ${ }^{61}$. The overall summary of the different molecular techniques is presented in Figure 4.

\section{CONCLUSION}

Several laboratory tests in the diagnosis of $\alpha$-thalassemia exist, which include both hematological and molecular testing. Molecular analysis for globin gene mutation is important for the definitive diagnosis, but hematological and clinical findings may not be helpful in some cases. HPLC and CE quantify the level of $\mathrm{Hb}$ and provide useful information in the diagnosis of specific thalassemia disease. However, different molecular techniques are used to detect globin gene mutation in this era, each having its advantages and limitations. PCR and DNA sequencing analyses 
are the main molecular techniques discussed in this study that can detect deletion and nondeletion $\alpha$-thalassemia mutations. Molecular techniques, namely Gap-PCR, LAMP, MLPA, and single tube multiplex PCR, are used to detect the common deletion of $\alpha$-thalassemia mutation. In addition, single-tube multiplex PCR can identify non-deletion mutations as well. On the other hand, DNA sequencing analysis can detect uncommon deletion and non-deletion mutations in the $\alpha$-globin gene, which is impossible by the PCR technique. Sanger sequencing is a commonly used best technique for thalassemia diagnosis. Still, this method cannot detect deletion mutation in the $\alpha$-globin gene, which is the common cause of $\alpha$-thalassemia. Therefore, NGS was recently introduced to detect novel and complex variations of $\alpha$-thalassemia. NGS is an effective method and it facilitates the screening of thalassemia but involves high costs. The diagnosis of $\alpha$-thalassemia is complex as the $\alpha$-globin gene is a highly variable genetic defect. Therefore, the selection of the diagnostic method depends on the equipment, expertise, cost involved, and facility of each diagnostic laboratory.

\section{REFERENCES}

1. Farashi $S$, Harteveld CL. Molecular basis of $\alpha$-thalassemia. Blood Cells Mol Dis. 2018;70:43-53. [CrossRef]

2. Kanias T, Acker JP. Biopreservation of red blood cells-the struggle with hemoglobin oxidation. FEBS J. 2010;277:343-56. [CrossRef]

3. Thein SL. The molecular basis of $\beta$-thalassemia. Cold Spring Harb Perspect Med. 2013;3:a011700. [CrossRef]

4. Higgs DR. The molecular basis of $\alpha$-thalassemia. Cold Spring Harb Perspect Med. 2013;3:a011718. [CrossRef]

5. Weatherall DJ, Clegg JB. The thalassaemia syndromes. John Wiley \& Sons; 2008.

6. Tan JA, Lee PC, Wee YC, et al. High prevalence of alphaand beta-thalassemia in the Kadazandusuns in East Malaysia: challenges in providing effective health care for an indigenous group. J Biomed Biotechnol. 2010;2010:706872. [CrossRef]

7. Thein S. Abnormalities of the structure and synthesis of hemoglobin. In: Blood and Bone Marrow Pathology. $2^{\text {nd }}$ ed. Edinburgh, UK: Churchill Livingstone (Elsevier Ltd); 2011. p. 131-50. [CrossRef]

8. Wahed A, Quesada A, Dasgupta A. Hematology and coagulation: a comprehensive review for board preparation, certification and clinical practice. Academic Press; 2019.

9. Harteveld CL, Higgs DR. Alpha-thalassaemia. Orphanet J Rare Dis. 2010;5:13. [CrossRef]
10. Sabath DE. Molecular diagnosis of thalassemias and hemoglobinopathies: an ACLPS critical review. Am J Clin Pathol. 2017;148:6-15. [CrossRef]

11. Piel FB, Weatherall DJ. The $\alpha$-thalassemias. N Engl J Med. 2014;371:1908-16. [CrossRef]

12. Babbs C, Brown J, Horsley SW, et al. ATR-16 syndrome: mechanisms linking monosomy to phenotype. J Med Genet. 2020;57:414-21. [CrossRef]

13. Vichinsky E. Complexity of alpha thalassemia: growing health problem with new approaches to screening, diagnosis, and therapy. Ann N Y Acad Sci. 2010;1202:180-7. [CrossRef]

14. Perumbeti A. Hemoglobinopathies and thalassemia syndromes. In: Pathobiology of Human Disease: A Dynamic Encyclopedia of Disease Mechanisms. Elsevier; 2014. p. 1506-31. [CrossRef]

15. Ünal S, Oktay G, Acıpayam C, et al. Hemoglobin $H$ disease in Turkey: experience from eight centers. Turk J Haematol. 2016;33:56-9. [CrossRef]

16. Viprakasit V, Ekwattanakit S. Clinical classification, screening and diagnosis for thalassemia. Hematol Oncol Clin North Am. 2018;32:193-211. [CrossRef]

17. Gilad O, Shemer OS, Dgany O, et al. Molecular diagnosis of $\alpha$-thalassemia in a multiethnic population. Eur J Haematol. 2017;98:553-62. [CrossRef]

18. Weatherall DJ, Clegg JB, Boon WH. The haemoglobin constitution of infants with the haemoglobin Bart's hydrops foetalis syndrome. Br J Haematol. 1970;18:35767. [CrossRef]

19. Munkongdee T, Chen P, Winichagoon P, Fucharoen S, Paiboonsukwong K. Update in Laboratory Diagnosis of Thalassemia. Front Mol Biosci. 2020;7:74. [CrossRef]

20. Cappellini MD, Cohen A, Porter J, Taher A, Viprakasit V, eds. Guidelines for the Management of Transfusion Dependent Thalassaemia (TDT). $3^{\text {rd }}$ ed. Nicosia (Cyprus): Thalassaemia International Federation; 2014. PMID: 25610943.

21. Urrechaga E, Borque L, Escanero JF. The role of automated measurement of RBC subpopulations in differential diagnosis of microcytic anemia and $\beta$-thalassemia screening. Am J Clin Pathol. 2011;135:374-9. [CrossRef]

22. Khera R, Singh T, Khuana N, Gupta N, Dubey AP. HPLC in characterization of hemoglobin profile in thalassemia syndromes and hemoglobinopathies: a clinicohematological correlation. Indian J Hematol Blood Transfus. 2015;31:110-5. [CrossRef]

23. Galanello R, Cao A. Gene test review. Alpha-thalassemia. Genet Med. 2011;13:83-8. [CrossRef]

24. Bain BJ, Wild BJ, Stephens AD, Phelan LA. Variant haemoglobins: a guide to identification. John Wiley \& Sons; 2011. [CrossRef]

25. Old J, Harteveld CL, Traeger-Synodinos J, Petrou M, Angastiniotis M, Galanello R. Prevention of Thalassaemias and Other Haemoglobin Disorders: Volume 2: Laboratory Protocols. $2^{\text {nd }}$ ed. Nicosia (Cyprus): Thalassaemia International Federation; 2012. PMID: 24672828.

26. Rosnah B, Nani Shahida S, Mohd Nazri H, et al. The diagnosis of beta thalassemia with borderline $\mathrm{HbA} 2$ level among Kelantan population. J Blood Disord Transfus. 2017;8:1000396. Available from: https://www.longdom. org/open-access/the-diagnosis-of-beta-thalassemiawith-borderline-hba2-level-amongkelantan-population2155-9864-1000396.pdf

27. Old J, Harteveld CL, Traeger-Synodinos J, Petrou M, Angastiniotis M, Galanello R. Prevention of Thalassaemias and Other Haemoglobin Disorders: Volume 2: Laboratory Protocols. $2^{\text {nd }}$ Ed. Nicosia, Cyprus, TIF Publications; 2012.

28. Sangkitporn S, Sangkitporn SK, Tanjatham S, et al. Multicenter validation of fully automated capillary 
electrophoresis method for diagnosis of thalassemias and hemoglobinopathies in Thailand. Southeast Asian J Trop Med Public Health. 2011;42:1224-32. PMID: 22299449.

29. You-Qiong L, Hui-Ping H, Zhi-Zhong C, et al. Comparison of capillary electrophoresis and high performance liquid chromatography for detection and quantification of hemoglobin New York. Clin Chem Lab Med. 2016;54:91 -5. [CrossRef]

30. Harewood J, Azevedo AM. Alpha Thalassemia. In: StatPearls. Treasure Island (FL): StatPearls Publishing; 2021.

31. Traeger-Synodinos J, Harteveld CL, Old JM, et al. EMQN Best Practice Guidelines for molecular and haematology methods for carrier identification and prenatal diagnosis of the haemoglobinopathies. Eur J Hum Genet. 2015;23:426-37. [CrossRef]

32. Old J, Traeger-Synodinos J, Galanello R, Petrou M, Angastiniotis $M$. Prevention of Thalassaemias and Other Haemoglobin Disorders: Volume 2: Laboratory Protocols [Internet]. 2nd edition. Nicosia (Cyprus): Thalassaemia International Federation; 2012. Available from: https:// www.ncbi.nlm.nih.gov/books/NBK190576/

33. Chan V, Yam I, Chen FE, Chan TK. A reverse dot-blot method for rapid detection of non-deletion alpha thalassaemia. Br J Haematol. 1999;104:513-5. [CrossRef]

34. Yang Y, Li DZ. Detection of uncommon deletions in alpha-thalassemia using the pcr-reverse dot-blot method for prenatal diagnosis of nondeletional hemoglobin $\mathrm{H}$ disease. Acta Haematol. 2010;124:9-12. [CrossRef]

35. Brancaleoni V, Di Pierro E, Motta I, Cappellini MD. Laboratory diagnosis of thalassemia. Int J Lab Hematol. 2016;38:32-40. [CrossRef]

36. Kho SL, Chua KH, George E, Tan JA. A novel gap-PCR with high resolution melting analysis for the detection of $\alpha$-thalassaemiaSoutheast Asian and Filipino $\beta^{\circ}$-thalassaemia deletion. Sci Rep. 2015;5:13937. [CrossRef]

37. Lam EPT, Chan CML, Tsui NBY, et al. Clinical applications of molecular technologies in hematology. J Med Diagn Met. 2013;2:1000130.

38. Sirichotiyakul S, Wanapirak C, Saetung R, Sanguansermsri T. High resolution DNA melting analysis: an application for prenatal control of alpha-thalassemia. Prenat Diagn. 2010;30(4):348-351. [CrossRef]

39. Turner A, Sasse J, Varadi A. Rapid detection of pathological mutations and deletions of the haemoglobin beta gene (HBB) by High Resolution Melting (HRM) analysis and Gene Ratio Analysis Copy Enumeration PCR (GRACEPCR). BMC Med Genet. 2016;17:1-13. [CrossRef]

40. Li X, Yang T, Li CS, Jin L, Lou H, Song Y. Prenatal detection of thalassemia by cell-free fetal DNA (cffDNA) in maternal plasma using surface enhanced Raman spectroscopy combined with PCR. Biomedical optics express. 2018;9(7):3167-76. [CrossRef]

41. Shaji RV, Srivastava A, Chandy M, Krishnamoorthy R. A single tube multiplex PCR method to detect the common alpha + thalassemia alleles. Blood. 2000;95:1879-80. [CrossRef]

42. Eng B, Patterson M, Walker L, Chui DH, Waye JS. Detection of severe nondeletional alpha-thalassemia mutations using a single-tube multiplex ARMS assay. Genet Test. 2001;5:327-9. [CrossRef]

43. Chong SS, Boehm CD, Higgs DR, Cutting GR. Single-tube multiplex-PCR screen for common deletional determinants of alpha-thalassemia. Blood. 2000;95(1):360-2. [CrossRef]

44. de Mare A, Groeneger AH, Schuurman S, van den Bergh FA, Slomp J. A rapid single-tube multiplex polymerase chain reaction assay for the seven most prevalent $\alpha$-thalassemia deletions and $\alpha \alpha \alpha$ anti $3.7 \alpha$-globin gene triplication. Hemoglobin. 2010;34:184-90. [CrossRef]
45. Schouten JP, McElgunn CI, Waaijer R, Zwijnenburg D, Diepvens F, Pals G. Relative quantification of 40 nucleic acid sequences by multiplex ligation-dependent probe amplification. Nucleic Acids Res. 2002;30:e57. [CrossRef]

46. Sankaran VG. Diagnostic Molecular and Genomic Methodologies for the Hematologist/Oncologist. In: Lanzkowsky's Manual of Pediatric Hematology and Oncology. 6th ed. Elsevier; 2016. p. 1-6. [CrossRef]

47. Liu JZ, Han H, Schouten JP, et al. Detection of alphathalassemia in China by using multiplex ligationdependent probe amplification. Hemoglobin. 2008;32:561-71. [CrossRef]

48. Colosimo A, Gatta V, Guida V, et al. Application of MLPA assay tocharacterize unsolved $\alpha$-globingenerearrangements. Blood Cells Mol Dis. 2011;46:139-44. [CrossRef]

49. Harteveld CL. State of the art and new developments in molecular diagnostics for hemoglobinopathies in multiethnic societies. Int J Lab Hematol. 2014;36:1-12. [CrossRef]

50. Chomean S, Pholyiam K, Thamwarokun A, Kaset C. Development of Visual Detection of $\alpha$-Thalassemia- 1 (the--SEA Deletion) Using $\mathrm{pH}-$ Sensitive Loop-Mediated Isothermal Amplification. Hemoglobin. 2018;42:171-7. [CrossRef]

51. Wang $\mathrm{WH}$, Lin $\mathrm{M}$, Li $\mathrm{HL}$, et al. Establishment and evaluation of a novel method based on loop-mediated isothermal amplification for the rapid diagnosis of thalassemia genes. Risk Manag Healthc Policy. 2020;13:303-11. [CrossRef]

52. Gill P, Amree AH. Allele-Specific Loop-Mediated Isothermal Amplification for the Detection of IVSII-I G>A Mutation On $\beta$-Globin Gene. Open Access Maced J Med Sci. 2019;7:1582-7. [CrossRef]

53. Li Y, Fan P, Zhou S, Zhang L. Loop-mediated isothermal amplification (LAMP): A novel rapid detection platform for pathogens. Microb Pathog. 2017;107:54-61. [CrossRef]

54. Keikha M. LAMP Method as One of the Best Candidates for Replacing with PCR Method. Malays J Med Sci. 2018;25:121-3. [CrossRef]

55. Notomi T, Okayama $\mathrm{H}$, Masubuchi $\mathrm{H}$, et al. Loopmediated isothermal amplification of DNA. Nucleic Acids Res. 2000;28:e63. [CrossRef]

56. Molchanova TP, Pobedimskaya DD, Postnikov YV. A simplified procedure for sequencing amplified DNA containing the $\alpha 2$-or $\alpha 1$-globin gene. Hemoglobin. 1994;18:251-5. [CrossRef]

57. Liu YT, Old JM, Miles K, Fisher CA, Weatherall DJ, Clegg JB. Rapid detection of alpha-thalassaemia deletions and $\alpha$-globin gene triplication by multiplex polymerase chain reactions. Br J Haematol. 2000;108:295-9. [CrossRef]

58. Dey P. Sanger Sequencing and Next-Generation Gene Sequencing: Basic Principles and Applications in Pathology. In: Basic and Advanced Laboratory Techniques in Histopathology and Cytology. Springer; 2018. p. 22731. [CrossRef]

59. Zhuang J, Tian J, Wei J, et al. Molecular analysis of a large novel deletion causing $\alpha+$-thalassemia. BMC Med Genet. 2019;20:74. [CrossRef]

60. He J, Song W, Yang J, et al. Next-generation sequencing improves thalassemia carrier screening among premarital adults in a high prevalence population: the Dai nationality, China. Genet Med. 2017;19:1022-31. [CrossRef]

61. Xu L, Mao A, Liu H, et al. Long-molecule sequencing: a new approach for identification of clinically significant DNA variants in $\alpha$-thalassemia and $\beta$-thalassemia carriers. J Mol Diagn. 2020;22:1087-95. [CrossRef] 